the production of better electrical sheet steels concern not only the practical steel-maker and the electrical engineer but also, for their solution, the physicist, the chemist and the experimental metallurgist. There is a great demand in the electrical industry for better electrical steels, particularly for transformers.

\section{Lepidopterous Larvæ in Stored Products}

WAR conditions have made it essential to know the numerous kinds of caterpillars, as well as of other insects, affecting stored food in Great Britain. It was soon found that with few exceptions the available descriptions of these larvæ are quite inadequate for identification purposes. Being based mainly on colour it became necessary to use more precise methods. In a useful paper entitled "The Larvæ of the Lepidoptera associated with Stored Products" (Bull. Entomol. Res., 163 ; Oct. 1943) by Dr. H. E. Hinton of the British Museum (Natural History), the chætotaxy and other structural features are relied upon for distinguishing the species. $\mathrm{He}$ deals with thirty-five species which include all the more important British kinds, together with seven which have not yet been recorded in Britain. In order properly to study the structure and chætotaxy of the larvæ it is necessary to preserve them in Pampel's fluid or alcohol or other preservative; dried specimens have, as a rule, too many of the critical setæ missing. Through the early researches of Dyar, Forbes and Fracker, and more recently of certain European workers, the classification of Lepidopterous larvæ has been placed on a relatively sound basis, although much still remains to be done.

\section{Tuberculosis Survey in the Western Pacific}

A GRANT of $£ 28,600$ has been made under the Colonial Development and Welfare Act to enable a tuberculosis survey to be made in Fiji. It is hoped to extend the survey to the British Solomon Islands Protectorate and the Gilbert and Ellice Islands Colony. The scheme will cover a preliminary survey only, mainly to determine the extent of the problem and the best means of dealing with it. A Government medical officer is undertaking preliminary work. A comprehensive scheme for the reorganization of the medical services of Fiji and the Western Pacific with assistance under the Act is contemplated, under which it is proposed to provide accommodation for four hundred cases throughout the area.

\section{Road Research}

A commitsee of the Road Research Board of the Department of Scientific and Industrial Research has been appointed "to survey the field for research on the use of machinery in road construction and, if thought fit, to draw up a programme of research". The Committee is constituted as follows : Sir George Burt, Mr. R. M. Wynne Edwards, Mr. A. Floyd, Mr. W. Minty, Mr. W. P. Robinson, Dr. W. H. Glanville (director of road research), and Mr. G. Bird (secretary).

The Department has also arranged to resume and extend its researches on concrete roads as part of the programme of the Road Research Board. The new work, which will have as its general aim the improvement of the standard of construction in respect of durability of surface characteristics, will be undertaken in co-operation with the Cement and Concrete Association. The Ministry of War Transport is co-operating in both these schemes.

\section{Earthquake in Turkey}

YET another large earthquake has taken place in Anatolia. On the morning of February 1, a strong earthquake occurred to the north-west of Ankara. The epicentre was near the town of Gerede, which is 180 miles east of Istanbul and about 60 miles from the Black Sea. In Gerede itself about four fifths of the houses were destroyed, and here and in the province of Bolu (in which Gerede is situated) 310 people were killed. In the province of Changiri 517 were killed, mostly at Tcherkesh, while in Zonguldak Province 25 people lost their lives. The effects of the shock were widespread, and in the villages north-west of Ankara 103 deaths as a result of the earthquake are reported. Altogether at least 955 people were killed by the earthquake and its effects, and some thousand others were injured. Faulting occurred along the motor-road from Ankara through Gerede and Bolu to Ismid, and communications were cut between Istanbul and the Kandili Observatory on the eastern shore of the Bosphorus. Snowstorms have hampered relief work. Strong tremors were felt at Adabazar, Ismid, Haidar Pasha, Smyrna, Kaisarieh and Brusa. The shock was registered at Kew Observatoryin England at 4.28 a.m., the maximum ground movement at $4 \cdot 41$ a.m. being greater than one millimetre. This is the fourth great earthquake, besides numerous others of smaller intensity, which has occurred since what was probably the greatest Turkish earthquake-that of Erzinjan in December 1939.

\section{Announcements}

Sir Harold Spencer Jones, Astronomer Royal, has been elected an honorary member of the American Astronomical Society.

Dr. Wrlliam Cullen, the distinguished consulting chemical and metallurgical engineer, has been elected president of the Science Masters' Association in succession to Prof. Frederick Soddy.

Prof. E. K. Rideal, professor of colloid science in the University of Cambridge, will succeed $\mathrm{Mr}$. Wallace P. Cohoe, a well-known American consulting chemist, as president of the Society of Chemical Industry, at the annual meeting of the Society to be held in July.

Prof. P. M. S. BLACkETT, Langworthy professor of physics at the University of Manchester, has been elected president of the Association of Scientific Workers as from February 1. During the War, Prof. Blackett is working for the Admiralty; he is widely known for his work on nuclear physics and cosmic rays.

THE Council of the Institution of Electrical Engineers having sanctioned the formation of a Wireless Group for Cambridge and District, a provisional committee has been approved, under the chairmanship of Mr. C. R. Stoner, with Mr. D. I. Lawson as secretary. The inaugural meeting will be held in the Engineering Laboratories of the University on February 17.

The A. Cressy Morrison Prize Committee for 1943 of the New York Academy of Sciences has awarded prizes of two hundred dollars each to W. A. Ritchie, Rochester Museum of Arts and Sciences, Rochester, N.Y., for a paper on "The Pre-Iroquoian Occupations of New York State", and to A. Grobman, University of Rochester, Rochester, N.Y., for a paper on "The Distribution of the Salamanders of the Genus Plethodon in Eastern United States and Canada". 